\title{
Czy Europa umiera - nasz głos $w$ dyskusji
}

\section{CZY MOŻNa ZASTANAWIAĆ SIĘ NA KOŃCEM UNII EUROPEJSKIEJ?}

JaCEK Raubo: Pytanie, czy Europa się kończy, jest tematem przewodnim niniejszych rozważań. Dyskusja w tym przypadku jest nad wyraz potrzebna, choć zauważyć należy, że niejednokrotnie budzi emocje, częstokroć skrajne. Nie ulega wątpliwości, że obecnie, na początku XXI w., cały kontynent europejski, boryka się z szeroką gamą różnego rodzaju problemów. Warto chociażby wspomnieć, że Europa, chociaż relatywnie bogata, traci na znaczeniu w kontekście globalnym. Społeczeństwa wielu państw starzeją się w zastraszającym tempie. Część państw nadal nie wypracowała spójnej i przede wszystkim skutecznej polityki wobec imigrantów, którzy dotychczas nie zasymilowali się z otaczającymi ich społeczeństwami. Niejako w środku całej dyskusji o stanie kontynentu zawsze znajduje się kwestia integracji europejskiej, tutaj symbolicznie utożsamiana z Unią Europejską. Sama idea integracji jest niewątpliwie wielkim sukcesem pokoleń Europejczyków, którzy po II wojnie światowej zapragnęli wyrzec się niszczycielskiej siły wojny i wspólnie pracować w duchu pokoju. Dzięki temu państwa funkcjonujące we wspólnocie odnotowały znaczny postęp i odbudowały się gospodarczo po zniszczeniach wojennych. Wraz z rozszerzeniami, które miały miejsce po zakończeniu zimnej wojny, niejako zatarciu uległ podział zbudowany w oparciu o żelazną kurtynę. Obecnie Europa szeroko korzysta z dobrobytu, ale należy nadmienić, iż czas zbierania owoców cudu gospodarczego, na bazie którego zbudowano UE, powoli mija.

Praktyka integracji dostarcza szeregu pozytywnych przykładów, jednakże obecnie, gdy w pewnym sensie można uznawać, że wizja jedności jest najbliższa realizacji, wyłoniły się dwie płaszczyzny, w ramach których nastąpiło tąpnięcie. Dwa duże bloki skumulowanych problemów, zagrażające niemalże całemu przedsięwzięciu, złowieszczo otaczają kontynent. Pierwszym polem walki, w nierozstrzygniętej jeszcze batalii o przyszłość integracji, stała się kwestia ideologicznej tożsamości nowej Europy. Od samego początku integracji ściera- 
ły się ze sobą dwie wizje jednoczenia Europy, a wraz z nimi postrzeganie wspólnych wartości. Jednak obojętnie, czy będzie to koncepcja wielu państw, czy jednego państwa federalnego, zawsze rodzi się pytanie o podbudowę całego konstruktu. Obecnie w głównym nurcie ruguje się, w pewnym sensie naturalne dla kontynentu, wartości związane z Judeo-chrześcijańską tradycją. Spór o preambułę do Konstytucji Europejskiej czy też sprawa Rocco Butiglione są tego dobitnym przykładem. W zamian oferuje się swoistą mieszankę quasi-wartości, w której odbijają się jeszcze echa rewolty 1968 r. Stąd nie może budzić zdziwienia sytuacja, szybkiego rozprzestrzeniania się w Europie religii takiej jak islam, opartej o silne przekonania i uznającej sztywny katalog wartości. Patrząc na świat, warto dostrzec, że główni, potencjalni rywale UE także dysponują trwalszymi fundamentami wartości. Stany Zjednoczone często są piętnowane za ich niejako dewocyjne podejście do wiary i wartości z nią związanych, które do tego jeszcze przekładają się na kształt państwa. Jednak nie można zaprzeczyć, że również dzięki takiemu podejściu do wartości państwo to było w stanie zbudować własną pozycję na świecie. W kontekście Chińskiej Republiki Ludowej trudno przecenić wpływ konfucjanizmu na rozwój tamtejszego społeczeństwa, gotowego do poświęceń w imię grupy. Czy Europa zamykanych kościołów i Europa odwołująca się jedynie do tradycji antycznej Hellady jest w stanie zmobilizować własnych obywateli do walki o przynajmniej utrzymanie obecnej pozycji na świecie? Należy zauważyć, że prozaiczna sprawa związana z rozpadem tradycyjnej rodziny w Europie może stanowić memento dla makrostruktury jaką jest UE.

Drugą kwestią jest dysfunkcjonalność szeregu rozwiązań zastosowanych w samym zarządzaniu Unią Europejską, w tym przypadku utożsamionych już przez większość Europejczyków z tzw. biurokracją brukselską. UE z narzędzia sprawnego rozwoju kontynentu powoli ewoluuje w coraz większą, a przy tym coraz bardziej ociężałą strukturę. Zapewne każdy mieszkaniec państwa członkowskiego UE jest w stanie podać przykład jakiegoś absurdalnego przepisu, którego korzenie sięgają Brukseli. Problem zapewne tkwi w popularnym w Europie przekonaniu, że zadekretowanie pewnych rozwiązań jest równoznaczne z ich późniejszym udanym wprowadzeniem w życie. Najgorszym symbolem mogą być próby odgórnego zainicjowania innowacyjności w gospodarkach państw członkowskich. Coś, co tak naprawdę powinno wypływać ze zwykłej obserwacji rynku, w Europie jest długotrwale rozważane i opisywane, przy tym jednocześnie w mierny sposób implementowane. W czasie, gdy w tzw. Dolinie Krzemowej w USA, 
centrach innowacyjności na południu Chin czy w Indiach, pewne działania przyspieszające rozwój najnowszych technologii są naturalne, w Europie częstokroć nie wychodzą poza sferę koncepcyjną w ośrodkach akademickich.

Zupełnie innego rodzaju problemem, ale także ściśle związanym z dysfunkcjonalnością UE jako struktury mającej budować rozwój gospodarczy, jest przerost świadczeń socjalnych. Nie dość, że państwa mają problem z ograniczaniem tego rodzaju wydatków, to jeszcze zauważalny jest trend, aby struktura UE była gwarantem utrzymania wielu z nich. Należy także przywołać przykład wspólnej polityki rolnej, której korzenie sięgają dążenia do uzyskania bezpieczeństwa żywnościowego dla państw po 1945 r. Obecnie jest to raczej oaza nadużyć, a przede wszystkim sztucznego sterowania rynkiem w zakresie rolnictwa, a do tego sowicie finansowana ze wspólnego budżetu. Bardzo interesująca jest także kwestia podejścia do szeroko pojmowanej ekologii. UE chcąc być przodownikiem na świecie w tym zakresie, wprowadza szereg ograniczeń i restrykcji dla przedsiębiorców, ograniczając automatycznie przy tym ich możliwości konkurowania z odpowiednikami z USA czy też ChRL. Część zmian przypomina w swej strukturze rewolucję, a nie ewolucję ku nowym standardom. Jednak czy narzucanie samemu sobie tak wysokich standardów nie będzie prowadziło do osłabiania całej struktury europejskiej? Oczywiście wskazując na kwestie innowacyjności, rozbudowanej polityki socjalnej czy też polityki rolnej, wprowadza się pewne uproszczenie, ale jest to działanie mające na celu ukazanie złego trendu, z którym dziś UE nie umie sobie poradzić. Należy również zauważyć, że brak jest współcześnie w UE określenia, czy struktura unijna ma przypominać skuteczną firmę przynoszącą zyski, czy też nad wyraz rozbudowaną wspólnotę wartości. Jeżeli miałaby być to, w pewnym sensie, firma należałoby zaakceptować rynek jako najlepszą weryfikację większości inicjatyw. Lecz jeżeli bliżej UE do wspólnoty wartości, to działania gospodarcze nie stanowiłyby celu samego w sobie, a jedynie byłyby elementem finansującym przedsięwzięcia. Współcześnie można zauważyć trend do preferowania tego drugiego scenariusza, ale ogranicza to potencjał ekonomiczny i wpływa na osłabienie siły całej UE. Można nawet uznać, że wobec globalizacji Europa sama się niejako ogranicza i traci możliwość reformowania się, by móc skuteczniej rywalizować z innymi regionami. Wiele państw potrzebuje jeszcze UE, bowiem jest ona w stanie przekazać im pomoc finansową - co jeśli nie będzie już jej na to stać? Wielka firma „Europa”, będzie podobna do jednego z wielkich zakładów pra- 
cy, w którym rozbudowane są przywileje pracowników, dba się nawet w sposób kuriozalny o ekologię, utrzymuje się setki, jeśli nie tysiące urzędników i kierowników, ale zapomniano o jednej rzeczy: już dawno przestano cokolwiek produkować z powodu braku kapitału. W ten sposób to, co kiedyś było atrakcyjne dla całego świata, stanie się tworem upadłym, a ludzie zamiast podnieść się i budować od nowa, będą nadal rozmyślali nad przeszłością.

Czy więc należy zastanowić się nad przyszłością kontynentu bez struktury UE? Historia wskazuje, że trzeba tworzyć tego rodzaju scenariusze zarówno na płaszczyźnie regionalnej, jak i narodowej. Nie chodzi w tym przypadku o negowanie samego faktu istnienia obecnej struktury, w której skupiła się integracja europejska, jednak o potrzebę wyciągania wniosków płynących z historii. Przecież nikt nie zaprzecza, że istotne jest dyskutowanie o osłabieniu tzw. Imperium Americanum, a więc dlaczego pomija się dyskusję o potencjalnym krachu koncepcji UE? Przecież Europa jako kontynent doświadczyła już wielu prób zjednoczenia, tworzenia sojuszy oraz towarzyszących im upadków wspólnych działań i z tego względu najlepiej powinna być przygotowana do dyskusji. W tym przypadku dochodzi do zaobserwowania jeszcze jednego kluczowego zagadnienia - wewnętrznej dynamiki i siły zmian na kontynencie europejskim. Współcześnie Europa nie może zaoferować światu tej samej wewnętrznej siły, która napędzała różnego rodzaju rewolucje, czy to polityczne, czy też gospodarcze. Społeczeństwa, które funkcjonują zazwyczaj w ramach bogatych państw Europy, stały się niejako pasywne w kreowaniu własnego otoczenia. UE jest dla nich symbolem ciągłości świata, w którym wszystko będzie bezpieczne, może nie jasne, jak to ma miejsce w przypadku procedur związanych z samym funkcjonowaniem unijnych gremiów, ale dające stabilność. Dlatego jakakolwiek dyskusja o przyszłości, w której trzeba byłoby potencjalnie tworzyć coś nowego w Europie, a do tego pracować dla innych pokoleń i to bez wizji własnego dobrobytu, jest tak trudna do zaakceptowania. Jednak brak dyskusji i uznawanie, że integracja europejska jest na tyle wyjątkowa, iż będzie trwała wbrew wszystkiemu, przypomina zaklinanie przyszłości. Wystarczy spojrzeć na dyskusję o zmierzchu Imperium Americanum i porównać ją do dyskusji o zmierzchu UE. W pierwszym przypadku mamy do czynienia z zażartą dysputą, uznawaną za kluczową w postrzeganiu świata, prowadzoną również z udziałem Europejczyków. Natomiast gdy dochodzi do prób dyskusji w drugim przypadku, są one traktowane raczej jako przejaw political fiction. Jednakże im bardziej Europa zamknięta bę- 
dzie na tego rodzaju kwestie sporne, tym bardziej odczuje brak przygotowania w momentach kluczowych dla jej przyszłości.

Mıкоєал Toмaszyк: W ostatnich latach w kontekście Unii Europejskiej w prasie specjalistycznej, publicystyce, wypowiedziach polityków i analityków pojawia się niesłuszne stwierdzenie, że projekt europejski jest bliski swego końca. W większości przypadków pojawia się przekonanie, że państwa członkowskie Unii nieudolnie zmierzają w kierunku uczynienia z niej bytu państwowego przenoszącego zdobycze państwa narodowego poza granice geograficzne państw UE-27 na granice zewnętrzne Unii. Argumentują tym samym, że od początku lat dziewięćdziesiątych poprzedniego wieku Unia Europejska ma problem z określeniem tego, czym jest. Z jednej strony zmierza w kierunku budowy wspólnej polityki zagranicznej i bezpieczeństwa, a w kontekście wydarzeń w Stanach Zjednoczonych z 11 września, dzieli się na państwa wchodzące w skład koalicji antyterrorystycznej i te nie należące do niej. $Z$ drugiej strony organizacja ta pokazuje dużą zdolność do zmiany i czegokolwiek by nie powiedzieć, efektywnie reaguje na zewnątrz i wewnątrzsystemowe determinanty zmian. $Z$ pewnością projekt europejski jest ofiarą swego sukcesu. Analizując motywy jakimi kierowali się „Ojcowie Europy” po drugiej wojnie światowej, gdy kreślili konstrukcję modelu integracji dla państw zachodnioeuropejskich, przyznać należy, że w większości ich cele zostały wypełnione treścią. W Europie nie obserwujemy dzisiaj punktów zapalnych, które miałyby się stać zarzewiem konfliktu ogólnoświatowego. Europa zwalczając źródła postaw nacjonalistycznych, stara się, aby podstawy jej wartości były oparte na zasadach wolności, demokracji, poszanowania praw człowieka i podstawowych wolności. Uzupełnieniem tego katalogu są zasady integracji europejskiej, które są elementem soft power Unii Europejskiej, za pomocą której podejmuje ona działania na arenie międzynarodowej. W wyniku procesu transformacji ustrojowej, państwa Europy centralnej kształtując podstawy swych niezależnych polityk zagranicznych, w większości orientowały się na akcesję do ugrupowań zabezpieczających je militarnie - Pakt Północnoatlantycki oraz ekonomicznie - Unia Europejska. Ostatnie rozszerzenie Unii było jednym z ostatnich celów, które efektywnie mobilizowały państwa Unii i państwa kandydującego do tego grona. Członkowie UE-15, widząc możliwość dopełnienia projektu europejskiego poprzez rozszerzenie jego zdobyczy na wschód kontynentu, podjęli się realizacji przynajmniej czterech wyzwań. Jednym z podstawowych jest debata nad przyszło- 
ścią Unii Europejskiej, która swym zasięgiem objęła dwa filary politycznej identyfikacji państw ją tworzących. Jak różne są optyki na to zagadnienie wśród państw UE-15, można się przekonać, analizując debatę ponicejską, przygotowującą prace Konwentu ds. Przyszłości Unii, oraz tę, która toczyła się na różnego rodzaju forach po nieudanej ratyfikacji TKE we Francji i w Niderlandach. Drugim jest konieczność przeprowadzenia niezbędnych do rozszerzenia zmian traktatowych, które wyznaczały ton konferencji międzyrządowych od Amsterdamu aż po Niceę. Trzecim wyzwaniem jest konieczność zachowania stabilnych podstaw rynku wewnętrznego, poprzez dywersyfikację możliwości partycypacji w jego mechanizmach, poparte okresami przejściowymi w zakresie możliwości podejmowania zatrudnienia przez nowych obywateli UE, czy w zakresie wsparcia w ramach mechanizmów dofinansowania polityki rolnej. Nie mniej istotna jest chęć przybliżenia Unii jej obywatelom, tak aby nie była w ich przekonaniu odbierana jako projekt elit.

W dniu dzisiejszym Unia Europejska ma nowe podstawy traktatowe, które umożliwiają jej, pytanie czy lepsze pozostaje otwartym, funkcjonowanie w poszerzonym składzie członkowskim. Trwa wypełnianie treścią i praktyką poszczególnych zapisów traktatów, chociażby w zakresie utworzenia korpusu służby działań zewnętrznych, uprawnień Wysokiego Przedstawiciela Unii ds. Zagranicznych i Polityki Bezpieczeństwa, czy też doprecyzowania traktatowych zasad procedury budżetowej. Przeciwnicy rozwiązań lizbońskich wskazują, że na przykładzie wyborów Stałego Przewodniczącego Rady (Prezydenta Rady), Wysokiego Przedstawiciela Unii ds. Zagranicznych i Polityki Bezpieczeństwa, a także obwarowania poszczególnych zapisów traktatu okresami przejściowymi, że mamy dowód na to, iż państwa członkowskie UE nie mają pomysłu na jej kształt, bądź też TL jest efektem ambitnych koncepcji wpisujących się w napięcie między dwoma scenariuszami rozwoju: Unii mocnej siłą jej państw bądź silnej jej instytucjami - przefiltrowanych przez poszczególne państwa członkowskie. Stąd Unia ma podstawy traktatowe takie, na jakie stać jej państwa członkowskie. Ich ocena może być dokonywana w stosunku do rozwiązań zaproponowanych w Traktacie Konstytucyjnym bądź też, co jest nie do końca trafnym kryterium porównawczym, w stosunku do innych bardziej lub mniej wyobrażonych podstaw traktatowych wspólnot państw, byłych bądź istniejących lub też nie mających szans na zaistnienie. Siła polityczna państw członkowskich Unii winna skupić się te- 
raz nie na debacie polizbońskiej, w którą wpisywane są mgliste scenariusze następnej zmiany traktatów.

Obserwuje się zmęczenie procesem reformy traktatowej, rozszerzeniem i kryzysem gospodarczym. Stąd też uwaga państw członkowskich winna skupiać się na opracowaniu realnej strategii wyjścia ze spowolnienia gospodarczego. Pracę nad dokumentem poddanym konsultacjom przez KE w grudniu 2009 roku pokazują skalę zróżnicowania wśród UE-27. Dotykają również fundamentalnych kwestii dotyczących modelu rynku, którego cechy mają zapewnić efektywną i konkurencyjną w skali światowej gospodarkę. Nadal aktualnym pozostaje napięcie między tym, co rozumiemy pod pojęciem polityki spójności, a tym, co wymusza konieczność działań doskonalących konkurencyjność europejskiej gospodarki w skali światowej. Państwa UE-10, UE-2 są żywotnie zainteresowane pogłębianiem zdobyczy rynku wewnętrznego. Szczególnie w zakresie dalszej liberalizacji rynku usług (dyrektywa usługowa), przeglądu założeń dyrektywy pracowniczej. Wychodząc z założenia, że największe korzyści z rozszerzenia przyniósł otwarty rynek wewnętrzny, dążą, w tym szczególnie nasze państwo, do ich maksymalizacji przez prace nad uzupełnieniem czterech swobód, piątą opierającą się na swobodnym przepływie wiedzy, technologii, know-how, osiągnięć sektora B+R. Od efektywnego wykorzystania innych niż mechanizmy Rady UE sposobów wpływu na prace nad projektami legislacyjnymi KE zależy sukces bilansujący niekorzystny względem nich nowy system głosowania w Radzie, który w znacząco inny sposób pozycjonuje aktorów unijnych na szczeblu tzw. political leadership.

Nowe państwa członkowskie są zainteresowane konsolidacją współpracy szczególnie w tych obszarach, w których zrealizowałyby swoje żywotne interesy. Na przykładzie Polski można wskazać na dążenie do wypełnienia treścią zapisów TL w zakresie wspólnej polityki energetycznej, Strategii na rzecz Morza Bałtyckiego czy też Partnerstwa Wschodniego. Sukces w tych obszarach zależy jednak od skali poparcia jakie zdoła się zyskać u pozostałych 26 graczy. Działa to w myśl zasady, że efektywny gracz przekonuje swoich partnerów do uznania przez nich jego pomysłów za własne. Swym zasięgiem Polska obejmuje również założenia Strategii Europa 2020, na podstawie której będą kreślone założenia prawne i finansowe nowej perspektywy finansowej na lata 2014-2020. Zróżnicowanie państw członkowskich, chociażby we wspomnianych zakresach, pokazuje, że nieuchronnie przedmiotem debaty winna być kwestia wpisania w realne mechanizmy współpracy elementu ją uelastyczniającego. TL nie jest w tym zakresie mar- 
twy, zaostrza jedynie kryteria włączenia do tego obszaru współpracy. Unia Europejska nie jest pogrążona w kryzysie politycznym. Nie znajduje się również na żadnym zakręcie dziejów, który miałby w zasadniczy sposób wpłynąć na jej przyszłość. Nie jest jednak zdolna do przeprowadzenia, niekoniecznej z dzisiejszego punktu widzenia, generalnej reformy traktatowej. Jeśli zmiany byłyby konieczne, ich opracowanie i wprowadzenie odbędzie się w drodze mechanizmów pozatraktatowych, np. regulaminy instytucji, porozumienia międzyinstytucjonalne (ostatnie PE z KE) i inne.

Unia nie jest $\mathrm{w}$ najbliższym czasie zdolna do rozszerzenia swego składu członkowskiego o tzw. państwa strategiczne, jak np. Ukraina i Turcja. Przyczyn jest wiele, ale jedna zasadnicza - przy braku reform finansowania poszczególnych polityk, w tym przede wszystkim rolnej i spójności, Unii nie będzie stać na taki krok. Nie ma realnej woli w gronie państw członkowskich, aby dokonywać w tych obszarach zasadniczych zmian. Aczkolwiek jednym z elementów programu politycznego nowego i starego przewodniczącego KE jest zaproponowanie zmian punktu dystrybucji środków strukturalnych z krajowego na brukselski. Nowe państwa członkowskie nie wyrażają na to zgody. Jedynym możliwym scenariuszem jest rozszerzenie o Chorwację i Islandię. Oba państwa zyskały w lutym 2010 pozytywny avis KE i wyraża się nadzieję na ich akcesję w okolicach roku 2012. Chcąc poszerzyć zakres oddziaływania państwom, które nie spełniają kryteriów akcesji lub z innych przyczyn nie mogą być członkami UE, będzie się proponowało, w ramach regionalizacji polityki zagranicznej, różnej kategorii ściślejsze sojusze, czy to w ramach partnerstwa, czy stowarzyszenia z Unią.

Państwa Unii Europejskiej są pogrążone w kryzysie gospodarczym. W dużej mierze jest on uzależniony od gospodarczych trendów ogólnoświatowych, ale również przez niektóre państwa członkowskie praktykujące „kreatywną księgowość” i tym samym pogłębiające stan niechęci i braku zaufania nie tylko w strefie euro. Jednym z determinantów rozwoju jest element kryzysowy, który dodatnio wpływa na przyszłą kondycję określonej struktury. Stąd Europa 2020 będzie testem solidarności unijnej, ale nie testem jej ogólnej kondycji. Sukces jest jednak uzależniony od spełnienia kilku warunków.

Po pierwsze pozytywnie ocenić należy oparcie wzrostu na nowych technologiach teleinformatycznych, przemyśle, tzw. zielonej energii oraz rozwijaniu sieci transportowej (sieci transeuropejskiej). Rząd polski pozytywnie ocenia propozycje działań w tym zakresie, 
jednak proponuje pobudzenie tych segmentów rynku w oparciu o rynek wewnętrzny, co ma przyczynić się do mniejszego subwencjonowania działań przez państwa bogatsze, aczkolwiek pozytywnie odnosi się do współpracy Francji i Niemiec w zakresie opracowania pakietu 70 ustaw wdrażających EU 2020 mimo braku konsensu co do jej ostatecznego kształtu. To rozegranie EU 2020 w ramach państw zaliczanych do grona „przywództwa politycznego UE” w istotny sposób zdominuje debatę szczytu Rady na wiosnę 2010 oraz wpłynie znacząco na pracę nad Nową Perspektywą Finansową 2014-2020. Po drugie, sukces Strategii zależy w dużej mierze od jakości zarządzania procesem jej wdrożenia oraz ewaluacji na poziomie państw członkowskich i Unii. Poszczególne działania państw członkowskich winny być konsultowane na poziomie europejskim. Po trzecie, w kontekście wydarzeń w Grecji z nadzieją spojrzeć należy na założenia KE w zakresie zarządzania polityką antyinflacyjną. Należy jednak wezwać KE do opracowania jednolitych procedur w tym zakresie, a państwa członkowskie do ich przestrzegania tak, by zachęcić je do większej solidarności w zakresie przeciwdziałania skutkom inflacji. Nowego znaczenia nabiera zasada solidarności. Po czwarte, nowe cele integracyjne Unii Europejskiej nie zawsze muszą być kreślone na realizację wielkich planów politycznych czy też gospodarczych. W większości stolic europejskich panuje przekonanie, że należy najpierw dobrze zagospodarować efekty rozszerzenia, zmiany traktatowej, by móc kreślić inne plany. W myśleniu o Unii wykreślić należy tę perspektywę państwowocentryczną. Tym samym unikamy debaty o potrzebie, bądź jej braku, opracowania traktatu konstytucyjnego, oddalamy debatę o wartościach bardziej lub mniej chrześcijańskich i innych. Unia jest bowiem organizacją międzynarodową o specyficznym, jednak nie państwowym charakterze, czerpiącą swoją siłę z kondycji jej państw członkowskich. Przybliżmy projekt europejski obywatelom i wsłuchując się w ich głos, budujmy Europę z nim zgodną.

\section{BEZPIECZEŃSTWO KONTYNENTU - OZNAKA SŁABOŚCI}

JaCEK RAubo: Rzymianie rozsądnie twierdzili, że si vis pacem, para bellum, aczkolwiek należy zastanowić się, czy w przypadku Europy w XXI w. nadal można uznawać tego rodzaju podejście za odpowiednią drogę do budowy własnego bezpieczeństwa. Państwa, aby mogły rozwijać się, potrzebują do tego odpowiednich warunków, a najważniejszym z nich jest niewątpliwie pozyskanie zabezpieczenia przed zewnętrzną ingerencją w ich sprawy. Najbardziej skrajną postacią owej 
ingerencji jest wojna lub innego rodzaju konflikt zbrojny. Po $1945 \mathrm{r}$. Europa chciała zapomnieć o traumatycznych przeżyciach z okresu obu wojen światowych i dzięki temu zbudowane zostały podwaliny pod pokój oparty na zasadach współpracy. Skupienie uwagi przez oba mocarstwa - USA i ZSRR na Europie jako polu potencjalnej płaszczyzny wojny pełnoskalowej niewątpliwie uchroniło kontynent od wszczynanych na całym świecie wojen lokalnych. Pokój wpisał się na trwałe w postrzeganie Europy z jej strukturami integracyjnymi. Jednak już wojna w byłej Jugosławii, a w późniejszym okresie konflikt w Kosowie, przypomniały, że nawet w samej Europie może dojść do działań zbrojnych. Co więcej, po 1989 r. destabilizacji poddane zostały regiony świata, w których wcześniej, dzięki rywalizacji dwóch bloków ideologicznych, zapewniony był względny spokój. Natomiast, jak pokazały zamachy z 11 września 2001 r. i późniejsze ataki terrorystyczne na cele w Londynie i Madrycie, sytuacja nawet w odległych geograficznie państwach może wpłynąć bezpośrednio na bezpieczeństwo w każdym innym miejscu świata. Od 4 kwietnia 1949 r. gwarantem bezpieczeństwa europejskiego, oczywiście patrząc na państwa demokratyczne, było NATO (a dokładniej rzecz ujmując USA) wspierane przez państwa członkowskie Sojuszu. Jednakże NATO, mimo tryumfu w zimnej wojnie, stanęło przed największym problemem utożsamianym z rozchodzeniem się wspólnych interesów USA i ich europejskich partnerów. W ten sposób wróciła koncepcja stworzenia dualizmu w zakresie bezpieczeństwa w Europie. Z jednej strony nadal akceptowane byłoby NATO, ale z drugiej UE miała zyskać możliwości wcześniej utożsamiane przede wszystkim właśnie z Sojuszem Północnoatlantyckim. Aczkolwiek w sytuacji, gdy NATO traci na znaczeniu, a UE pod względem możliwości nie jest w stanie zapewnić odpowiednich sił i środków, istnieje obawa, że Europa nie jest aż tak bezpieczna, jakby można było sądzić. Jest to sytuacja niebezpieczna nie z powodu konkretnego zagrożenia np. inwazją wrogiego państwa w krótkiej perspektywie czasu, ale długoterminowych skutków tego rodzaju słabości.

Jakie są więc możliwe scenariusze w kwestii bezpieczeństwa Europy zorganizowanej w strukturę UE? Pierwszy, zakłada optymistyczną wizję, w której Europa pozostaje wolna od konfliktów i zawirowań, w których potrzebne będzie użycie siły. Jednocześnie, w tym samym przypadku, wzorzec europejski jest na tyle interesujący dla innych państw świata, że pozycja reprezentującej kontynent UE wzrasta nawet bez rozwijania podbudowy w aspekcie klasycznej siły. Trzonem stają się możliwości w zakresie tzw. soft power Europy. NATO prze- 
staje być paktem obronnym sensu stricte i zyskuje wymiar podobny do Rady Europy, tylko że w wymiarze szeroko pojmowanego bezpieczeństwa. Być może nawet NATO, postrzegane jako archaiczna zimnowojenna forma zostaje rozwiązane lub podlega marginalizacji, jak to miało to miejsce z Unią Zachodnioeuropejską. Jednakowoż, aby tego rodzaju scenariusz mógł być zrealizowany świat powinien podążać w kierunku pokoju i procesów rozbrojeniowych, a jest to założenie nad wyraz idealistyczne.

Scenariuszem, który wydaje się bardziej realny, jest osłabienie NATO i przeniesienie większości odpowiedzialności za obronę nie tylko Europy, jako konkretnego terytorium ale i jej interesów, na UE w ramach Polityki Bezpieczeństwa i Obrony. Tego rodzaju działanie wymagałoby od państw członkowskich przede wszystkim woli stworzenia znacznych sił i wydzielania środków na ich utrzymanie. Bez sił amerykańskich potrzebne byłoby m.in. stworzenie zaplecza pod flotę samolotów transportowych, niezbędnych przy współczesnej projekcji sił. Rodzi się jednakże pytanie, na ile Europa jest zdeterminowana jako całość, aby stworzyć nową jakość na płaszczyźnie bezpieczeństwa i obrony. Patrząc przez pryzmat obecnej misji ISAF w Afganistanie, dostrzec można, jak problematyczne jest funkcjonowanie struktury opartej o różne zasady użycia siły, dysponującej różnej klasy uzbrojeniem, a nawet różniącej się wolą walki. W przypadku gdyby to UE miała zastąpić NATO i przede wszystkim Stany Zjednoczone, niewykluczone byłoby zaistnienie sytuacji kryzysowej, w której pojawiłyby się straty w sprzęcie, a przede wszystkim w ludziach. Wówczas jednym z problemów byłoby na pewno utrzymanie woli politycznej do kontynuowania działań, być może nastąpiłyby także napięcia w obrębie kontyngentów narodowych. W przypadku wskazanego scenariusza, wymagany byłby postęp w procesach integracyjnych.

Trzecią możliwością byłoby dalsze utrzymywanie swoistego dualizmu NATO - UE. Tego rodzaju rozwiązanie związane byłoby z niechęcią do przejmowania pełnej odpowiedzialności za własne bezpieczeństwo przez UE od NATO, ale przy jednoczesnym dążeniu do pragmatycznego podtrzymywania obecności Stanów Zjednoczonych w strukturze gwarancji bezpieczeństwa. Problemem może być stosunek USA do takich działań, w których to wymaga się od Ameryki, ale w mniejszym stopniu wspiera się jej wysiłki. Taka dwuznaczność w relacjach transatlantyckich byłaby jednak niefunkcjonalna dla obu stron i mogła prowadzić do ich osłabienia. Najbardziej pragmatyczne byłoby, w przypadku osłabienia NATO oraz niemożliwości uzyskania pełnych 
zdolności przez struktury w ramach UE, powołanie wielu mniejszych sojuszy między konkretnymi państwami. Jednocześnie państwa powróciłby do samodzielnego budowania strategii opartych w większym stopniu o ich własny potencjał aniżeli sojuszniczy. W tym wypadku siła Europy uległaby osłabieniu i spadłaby zdolność do działania poza granicami kontynentu. Wzrosłaby jednak siła poszczególnych państw, gdyż musiałyby one reformować strukturę własnego bezpieczeństwa pod konkretne zagrożenia, nie zdając się na innych.

Zapewne nie istnieje jedno poprawne rozwiązanie dla Europy w zakresie zapewnienia bezpieczeństwa, ale należy zauważyć, iż musi ono zawierać kilka wspólnych elementów. Przede wszystkim precyzyjne ustalenie priorytetu strategicznego, co jednoznacznie jest związane z wyborem pomiędzy utrzymywaniem dysfunkcjonalnego dualizmu NATO - struktury UE zajmujące się bezpieczeństwem i obronnością. Kolejną z działań byłoby zarysowanie katalogu wspólnych zagrożeń stojących przed Europą na początku XXI w., aby czytelnie odejść od konstrukcji budowanych jeszcze w oparciu o relacje zimnowojenne, a następnie dokonanie podziału sił i środków w kontekście uznanych za strategicznie i ważne dla przyszłości kontynentu. Obojętnie, czy zostanie to dokonane w ramach NATO, czy rozbudowanej UE, będzie to proces długotrwały i wymagający aktywności wszystkich państw. Zachowanie dalszej bierności przez Europę na początku XXI w., może skutkować, z jednej strony osłabieniem znaczenia kontynentu w kwestiach międzynarodowych, a z drugiej być zachętą do narzucania pewnych rozwiązań przez mocarstwa dysponujące rozbudowaną siłą w klasycznym rozumieniu. W pewnym sensie to właśnie przez pryzmat bezpieczeństwa i obronności będzie można najlepiej ocenić, czy mamy do czynienia z jedną Europą, czy nadal z konglomeratem państw, które w pewnych okresach współpracują ze sobą.

Świat nadal wymaga od państw sprawnego zarządzania własnym bezpieczeństwem, jednocześnie globalizacja zmusza do poszukiwania nowych narzędzi oddziaływania. Współcześnie Europa stoi przed dylematem, jak skonstruować wizję własnego bezpieczeństwa i nadal nie znalazła czytelnej odpowiedzi. Rodzi się pytanie, czy ten trawiący kontynent problem zostanie rozwiązany do momentu, gdy zakończy się czas wynikający z dywidendy pokoju uzyskanej po 1989 r., wówczas bowiem, tak często wskazywana rola soft power, może być niewystarczająca. Powtórzmy raz jeszcze, si vis pacem, para bellum. 
MıкоєAJ Toмaszyк: Zasadniczym dylematem jest odpowiedź na pytanie, czy państwa Unii Europejskiej chcą potwierdzać swoje bezpieczeństwo w formule NATO, czy dążyć do jej europeizacji bądź też budowy swojego sytemu bezpieczeństwa. Wraca tym samym debata o pakcie muszkieterów nie tylko w rozumieniu bloku państw pomagających sobie w razie zagrożenia braku dostaw surowców energetycznych, ile jako bloku państw połączonych silnym wojskowym sojuszem, częściowo, bądź w całości niezależnym do NATO. Dyskusja na ten temat była głośna na salonach europejskich w latach 2004 - 2005. Nie wyniknęło z niej nic, a analiza debaty o remilitaryzacji sił wojskowych RFN pokazuje, że w najbliższym czasie realnym wydaje się scenariusz NATO bez reformy. Nie da się bowiem zbudować silnego bloku wojskowego w Europie bez udziału jednego z najbardziej wpływowych aktorów.

\section{UE - AKTYWNY GRACZ NA ARENIE MIĘDZYNARODOWEJ?}

JACEK RAubo: Współcześnie Unia Europejska jest złożona z państw mających własne interesy w różnych regionach świata. Jednocześnie istnieje silne przekonanie, że to cała UE powinna odgrywać rolę globalnego gracza, stojąc u boku takich potęg jak Stany Zjednoczone, Federacja Rosyjska, ChRL czy też Indie. Prowadząc rozważania w tym kierunku, można spróbować wyjść poza obecny partykularyzm państw członkowskich i zastanowić się nad hipotetyczną sytuacją, gdy to UE będzie odpowiadała za całokształt relacji zewnętrznych. Na pierwszym miejscu automatycznie pojawia się pytanie, w jaki sposób konstruować w przyszłości taką aktywność międzynarodową UE? Czy nadal prowadzić działania w oparciu o budowanie dużej ilości inicjatyw na całym świecie, uznając, iż przyniosą one w perspektywie zyski? Być może należy jednak, stosując sprawdzone w historii przez wielkie mocarstwa metody, dokonać swoistej twardej selekcji kierunków zaangażowania międzynarodowego. Celem takich działań byłoby ukierunkowanie wszystkich starań pod konkretne potrzeby Europy, pozostawiając na boku wizje związane z potrzebą krzewienia wartości europejskich. Tego rodzaju odejście, a wręcz w praktyce zerwanie z idealizmem i przejście na pozycję nacechowaną pragmatyzmem, nie byłoby trudne do zaakceptowania z jednej prostej przyczyny - obecne państwa członkowskie, mimo odniesień do sfery wartości, i tak stawiają na pierwszym miejscu własne korzyści i zyski. Dlatego postulowane byłoby wybranie i dogłębne skoncentrowanie się na kilku kluczowych dla interesów kontynentu europejskiego regionach świata. Przykładem takiego postępowania mogą być Stany Zjednoczone z ich obecno- 
ścią w Zatoce Perskiej. Obok uznania dominacji pragmatyzmu, w postępowaniu całej UE jako gracza międzynarodowego, kluczowym byłoby zarysowanie podstawowych wyznaczników w doborze odpowiednich wektorów w polityce na arenie międzynarodowej.

Po pierwsze, wizję polityki międzynarodowej należałoby oprzeć o potrzeby gospodarcze, takie jak zapewnienie surowców naturalnych czy też w mniejszym stopniu utrzymanie lub zdobycie nowych miejsc zbytu towarów produkowanych w Europie. Odnośnie surowców naturalnych najlepiej dostrzec obecną słabość UE, albowiem wypracowanie minimalnego zarysu wspólnej polityki w tym zakresie w kontekście partykularnych interesów państw członkowskich, stwarza wielkie problemy. $Z$ jednej strony daje to asumpt do dalszych rozważań co do przyszłości całej UE, a z drugiej wskazuje, że potencjalne różnice mogę negatywnie oddziaływać na postrzeganie siły zjednoczonej Europy w świecie. Wobec tego trudno domniemywać, że jeżeli kłopoty pojawiają się już na linii porozumienia z Federacją Rosyjską, to będą skutecznie prowadzone jednorodne działania, jeśli do gry o surowce w jakimś konkretnym miejscu świata włączą się także gracze, tacy jak USA czy ChRL. Stąd też należy jak najszybciej dokonać swoistego wartościowania w kontekście interesów gospodarczych, gdyż dostrzegalny jest niejako nowy podział świata na strefy wpływów gospodarczych, który zainicjowały nowe wzrastające w siłę potęgi, na czele z ChRL. Już dziś widać to w kontekście rozgrywki w Azji Centralnej, chociaż najlepszym polem do analizy tego rodzaju wyścigu jest jednak Afryka. Działania podejmowane w celu zapewnienia bezpieczeństwa energetycznego muszą cechować się determinacją i skuteczną strategią. W żadnym wypadku nie można działać ad hoc lub zdać się na konsensus pomiędzy zainteresowanymi stronami. Liczy się szybkość działania i skuteczność, w tym wypadku mierzona wymiernymi zyskami gospodarczymi. Każde działanie, każda inicjatywa, a w szczególności każde wydane pieniądze powinny skutkować dobrymi kontraktami, nowymi liniami energetycznymi, a upraszczając, po prostu zyskiem, jak nie całej UE, to poszczególnych firm działających w Europie.

Drugą z determinant $\mathrm{w}$ ramach potencjalnej stratyfikacji kierunków aktywności UE na świecie powinna stać się potrzeba uzyskania trwałego sojuszu lub sojuszy na miarę XXI w. Jeżeli analizie zostanie poddany koniec XX w., to czytelnie będzie można zauważyć, iż rolę owego gwaranta integracji na kontynencie europejskim, nawet wbrew krytycznym opiniom np. Francji, odgrywały Stany Zjednoczone. Jednakże obecnie USA są coraz mniej zainteresowane stwarzaniem ide- 
alnych warunków pod rozwój konkurencji dla własnych interesów. Dawniej partnerzy, w postaci USA i Europy, potrzebowali się nawzajem, gdyż stanęli w obliczu realnego zagrożenia ze strony ZSRR. USA niejako potrzebowały rozwiniętej Europy, a Europa musiała zdać się na amerykański parasol bezpieczeństwa. Na dziś obie strony mogą swobodnie poszukiwać sojuszników w kontekście konkretnych zagrożeń definiowanych własną racją stanu. I tu po raz kolejny pojawia się pytanie, czy zaistnieje jedna europejska racja stanu. Przy założeniu, że nastąpi unifikacja interesów państw członkowskich, należy zauważyć, że UE jest obecnie w zupełnie innej sytuacji od USA. Wynika to z faktu, iż dopiero wraz z zakończeniem zimnej wojny Europa uzyskała pełną swobodę działania na zewnątrz kontynentu. Od 1945 r. państwa Europy raczej traciły na znaczeniu w relacjach globalnych, czego symbolem były upadające imperia kolonialne. Dziś UE może na nowo starać się o wejście w sferę relacji globalnych, w ramach których kiedyś funkcjonowały jej pojedyncze państwa członkowskie. Należy dostrzec, iż nie jest to twierdzenie nie bazujące na realnych możliwościach. Przede wszystkim Europa ma do tego szereg atutów, do których należą wspomniane dawne tradycje kolonialne, postrzegane jako sieć powiązań kulturowych i politycznych z elitami w innych regionach świata. Jednocześnie UE symbolizuje współpracę, pokój i dobrobyt, a więc wartości poszukiwane w regionach targanych sporami i konfliktami. Nie do przecenienia jest również bogactwo państw europejskich. Jednak trudno przypuszczać, że UE będzie w stanie sama uzyskać pozycję, jaką miała w obliczu współpracy transatlantyckiej. Jakie są w takim razie możliwości?

Najbardziej klasyczną jest próba utrzymania ścisłych relacji z USA, wykazując że oba podmioty są predestynowane do wspólnego działania. Opcją najbardziej optymalną z punktu widzenia Europy jest wytworzenie ośrodka na miarę państw niezaangażowanych w okresie zimnej wojny. Wówczas UE miałaby w takiej strukturze pozycję dominującą i jednocześnie spełniłyby się oczekiwania wielu państw świata o zerwaniu z dominacją USA. W tym miejscu należy zaznaczyć, iż taka wizja wymagałaby perfekcyjnego wręcz połączenia działań dyplomatycznych, gospodarczych, a przede wszystkim dużej jednorodności w samej UE. Godną zauważenia jest możliwość nawiązania strategicznego sojuszu z jedną ze wschodzących potęg światowych. Byłoby to działanie obustronnie korzystne, bowiem każda ze stron miałaby dostęp do brakujących jej atrybutów. Jednakże w tym przypadku należałoby brać pod uwagę potrzebę uznania, iż taki sojusz wiązałby się z cią- 
głym zagrożeniem wynikającym z chęci dominacji jednej ze stron i nie musiałaby być to wcale dominacja Europy.

W każdym z zarysowanych scenariuszy kluczowe będzie określenie jasnych kryteriów dla przyszłych strategicznych sojuszy. Należy oprzeć się na założeniu, że jeżeli chce się być aktywnym graczem na arenie międzynarodowej, to trzeba działać pragmatycznie i nader szybko reagować na każdy kryzys. Najgorszym z możliwych rozwiązań byłoby stwierdzenie, że reszta świata winna dostosować się do standardów i zasad wyznawanych przez Europę tylko na zasadzie uznania ich za coś wyjątkowego. W globalnej rozgrywce analizuje się za każdym razem potencjał, określa zasoby i dostrzega słabe strony każdego z partnerów lub rywali. Jeżeli UE ma pretendować do odgrywania roli jednego z liderów w XXI w., musi przede wszystkim pokazać czytelnie reszcie świata, oznaki własnej słabości i poszukać dróg ich przezwyciężenia, ale tylko przez skuteczne działania, a nie deliberację. Dodatkowo należy wypracować konsensus co do kierunków zaangażowania i sposobów oddziaływania na innych graczy. Jeżeli ma to nadal być w głównej mierze soft power, trzeba uzyskać choć minimalny potencjał w sferze klasycznej siły, aby móc stosować ten atut bez obawy przed zagrożeniami. Najważniejszym jest zrozumieć, iż świat nie będzie czekał na wewnętrzne przeobrażenia w Europie w nieskończoność. Toczy się stała rywalizacja o wpływy, rynki zbytu, surowce itp., a tylko zdeterminowani i umiejący wykorzystywać doświadczenia swoje i innych są w stanie kreować zmiany w skali globalnej. Inaczej UE pogrąży się w dyskusjach ukierunkowanych do wewnątrz i nigdy nie będzie liczącym się graczem w skali makro.

Takie osłabienie zjednoczonej Europy jako gracza w świecie, będzie niosło także zagrożenia związane z samą integracją. Państwa, takie jak Wielka Brytania, RFN czy też Francja chcąc pozostać w grze o najwyższe stawki będą odcinały się od nieudolnej w tym zakresie struktury ogólnoeuropejskiej lub w najlepszym razie, co czynią obecnie, będą ją traktowały instrumentalnie w kontekście własnej polityki. Jednakże czy tak naprawdę UE musi być graczem międzynarodowym? Może należy zaakceptować fakt, iż polityka zagraniczna winna leżeć w gestii poszczególnych państw lub sojuszy państw, a nie jednej organizacji. Jedną z opcji jest w tym wypadku strategia oparta na zasadzie: znaczyć mniej, ale działać skuteczniej. Świat przecież doświadczył w swej historii wielu imperiów, które jedynie na przysłowiowym papierze znaczyły wiele, zaś w praktyce rozsypywały się w obliczu kryzysu. 


\section{SUMMARY}

THE AUTHORS OF THE ARTICLE discuss selected shortcomings of European integration, concentrating on such problems as a future vision of Europe, its position in international and global relations, as well as the process of building common security structures. The article is based on the assumption that Europe needs to rethink and openly analyze its problems that have arisen in the $21^{\text {st }}$ century.

\section{NOTY O AUTORACH}

Jacek Raubo [jacek.raubo@amu.edu.pl] - absolwent politologii na Wydziale Nauk Politycznych i Dziennikarstwa UAM w Poznaniu; specjalizacja stosunki międzynarodowe. Doktorant na tym wydziale w Zakładzie Systemów Politycznych. Zainteresowania naukowe związane z stosunkami międzynarodowymi, konfliktami zbrojnymi po 1945 r., obronnością i bezpieczeństwem, systemem politycznym Stanów Zjednoczonych.

Mikołaj Tomaszyk [mikolaj.tomaszyk@amu.edu.pl] - absolwent politologii na Wydziale Nauk Politycznych i Dziennikarstwa UAM w Poznaniu, specjalizacje: administracja samorządowa i integracja międzynarodowa. Doktorant na tym wydziale w Pracowni Badań nad Integracją Europejską. Członek zarządu Ośrodka Badań i Edukacji Europejskiej, członek grupy konwersatoryjnej „Prawo i polityka Unii Europejskiej”. Główny wykonawca grantów Komisji Europejskiej związanych m.in. z problematyką korupcji w państwach UE, deficytem demokracji w UE, kwestiami polityki społecznej. Współzałożyciel Poznańskiego Ośrodka Myśli Europejskiej. Zainteresowania naukowe związane z przyszłym kształtem Unii Europejskiej, obywatelskim wymiarem procesu integracji europejskiej, transformacją ustrojową w państwach Europy Środkowej i Wschodniej. 